\title{
Engadine
}

\section{Helen McDonald}

The township of Engadine in Sutherland Shire is on the Old Princes Highway (formerly Princes Highway) and the Illawarra railway line. It borders the Royal National Park on the eastern side and is sited along a ridge with a steep decline to the Woronora River to the west. It is very rocky with underlying layers of Hawkesbury sandstone and shallow topsoil.

The earliest inhabitants of Engadine were the Dharawal people.

In 1844, a road from Sydney to the Illawarra district was opened, which established access to an area near the Woronora River in the parish of Heathcote. However, the road was not well used as it was difficult to traverse, and cargo was generally transported by ship down the coast. ${ }^{1}$ By 1865 , a new route was established from Sylvania.

\section{Charles McAlister's Engadine}

Once crown land, the area which became known as Engadine was originally attached to the village of Heathcote, which had been proclaimed in July 1886. The Illawarra railway from Sutherland to Waterfall opened in March 1886 and Heathcote was initially established as a railway community.

Charles McAlister of Petersham purchased about 17 acres (7 hectares) of this suburban land to the north of Heathcote, following Old Illawarra Road (later Woronora Road) towards the Woronora River. McAlister felt that the hills and valleys of the area bore a striking resemblance to the Engadine valley in Switzerland. The fact that the European region was also close to a national park inspired him to acknowledge the similarity by naming his estate Engadine. This name later encompassed the whole township.

McAlister came to New South Wales from Ireland in 1866 at the age of 22. He operated a grocery business in Sydney and was at one time a pearl merchant. With his wife Christina, McAlister built a house named Sunbeam Cottage on the Old Illawarra Road in about 1888, making him the first settler. In about 1897 he extended the cottage and renamed it Holmlea. In 1906 McAlister was nominated with five others to form the first council of the Shire of Sutherland. Elected to the first council, he served until $1913 .^{2}$

\section{Engadine expands}

Allotments of crown land in the village of Heathcote were again sold in 1904 and 1910. Some of the land was purchased primarily for speculation, although a progress association was in operation and an application was made by Sutherland Shire Council to allocate a 10-acre (four 
hectare) reserve for a school. The land was promoted as suitable for fruit growing and poultry farming. ${ }^{3}$

In 1915, the Waratah Recruiting March for soldiers from the south coast passed through Engadine. A puppy was offered to the marchers as a mascot by the Hanlon family, who had established a small holding with a substantial garden. ${ }^{4}$

In 1916 Charles McAlister recommended that crown land should be offered for the settlement of returned soldiers. He also offered part of his own estate for sale, advocating Engadine as the 'sanatorium of the south'. By this time several other families had taken up land and built cottages to enjoy the tranquillity and rural character of the area.

\section{Soldier settlers}

In 1916, 22 blocks were offered to returned soldiers. One of the first to take up this offer was Arthur Bower, who set up a poultry farm. Others soon followed, and this resulted in agitation for further services for the growing settlement.

As early as 1916 there had been discussions among local residents about the importance of having a railway platform. This section of the Illawarra line had been open for 30 years with no stop between Sutherland to the north and Heathcote to the south. In about 1919 the locals formed the Engadine Platform League to lobby for a platform. In 1920 a station was built, following hard work and a financial contribution from the league.

It was felt that this achievement would be a boon to those who had taken up the allotments made available for soldiers. In 1921, some residents of Heathcote and Engadine formed a joint association to continue this progress. The construction of the railway platform also further encouraged land subdivision, with an area subdivided by local real estate agent Joseph Preston. By 1929 there were enough residents to warrant another application to the Department of Education for a school.

Many families took advantage of a further subdivision opened up by the Crown Lands Department in 1931. The scattered settlement was united through their progress association, which continued to agitate for essential services. In 1931 the Engadine Literary Institute (School of Arts) building was opened. With 111 dwellings and a population of 417, Engadine was officially proclaimed a village in $1933 .{ }^{5}$ A provisional school, which had commenced in September 1932, was officially opened in November 1933.

\section{Relief for the unemployed}

In 1935 a large area of crown land at north Engadine was subdivided by the government for unemployed city-dwellers. By 1936 the residents of north Engadine had formed a progress association of their own, to address issues such as the provision of roads and other basic services. 
Due to the large number of children at north Engadine, an application was also made for a new public school. It was refused on the grounds that the area was a settlement of relief workers and residents might 'drift off' as soon as times improved. ${ }^{6}$

In 1940 an inspection of the camp found that it was in a deplorable condition. Thirty-five families were living in iron, hessian and bush timber shacks built with the $£ 15$ government shelter allowance. Despite this, and unlike many other unemployment camps of the time, the area became permanently settled and later formed part of the suburb of Yarrawarrah. Some of the World War I soldier settlers went on to serve again in World War II.

\section{Boys' Town}

In 1940, due to the drive and determination of Father Thomas Dunlea, a home for boys known as Boys' Town was established in Engadine. The boys received a general education and two trade schools were set up on site to train them in butchery and baking. In 1942 members of the De La Salle Brothers arrived to care for the boys. When Father Dunlea died in 1970, his body was buried within the grounds.

\section{A growing population}

By 1940 there were 23 poultry farms in Engadine. ${ }^{7}$ Although there was a lack of essential services, Engadine did have a maternity hospital, which opened in 1950. Many local families used this facility, as the closest general hospital was at Kogarah.

The progress association noted in 1951 that the location of the Royal National Park, flanking the eastern side of the railway line, was a disadvantage to the progress of Engadine, which could develop only on one side. It also made the town vulnerable to bushfire.

The shopping area built up gradually around the main road through the town, the Princes Highway. For many years this was one of the only formal roads. Others, such as Station Street, were like 'bush tracks'. In 1965 it was planned to move the highway away from the shopping centre in order to widen the road. In 1969, with the new road completed, the old section was renamed the Old Princes Highway.

By 1971 the population stood at 18,183. The release of crown land at regular intervals throughout the ensuing years, particularly in north Engadine, led to a continued increase in the population.

\section{The town comes of age}

The decades following 1971 saw the introduction and upgrade of a number of services. The needs of local secondary students were met with the opening of Engadine High School in 1969 and St John Bosco College in 1978. The opening of an Olympic pool in Anzac Avenue in 1975 was a welcome addition. Electrification of the suburban railway line to Waterfall from 1980 made 
public transport to and from Engadine much easier. The Engadine Bush Fire Station was upgraded in 1980 and again in 2000, and a purpose-built police station opened in 1981 in Caldarra Avenue. Artificial wetlands were created in 1994 in the Royal National Park near Engadine station and in 1997 opposite Engadine Avenue to help reduce pollution.

In 1990 the first mall was established in the town centre when Engadine Court opened for business. At about the same time, a community centre opened opposite the shopping mall to accommodate facilities such as child-care services and later the new Engadine Library, which opened in 1998.

A community spirit still drives local residents to continue to improve the area, while the past is also celebrated. The inaugural McAlister Day Fair, named in honour of the pioneer Charles McAlister, was held in 2000.

Helen McDonald is local studies librarian at Sutherland Library

\section{Endnotes}

${ }^{1}$ Frank Cridland, The Story of Port Hacking, Cronulla and Sutherland Shire, Angus \& Robinson, 1950, p 85

${ }^{2}$ Joan Thompson, Engadine, New South Wales: An Outline History, Lions Club of Engadine, Engadine NSW, 1991, p 8

${ }^{3}$ The Propeller, 24 May 1912

${ }^{4}$ A Clark, The Waratahs: South Coast Recruiting March, 1915, the author, 1994, p 27

${ }^{5}$ Joan Thompson, Engadine, New South Wales: An Outline History, Lions Club of Engadine, Engadine NSW, 1991, p 19

${ }^{6}$ Colin Lock, History of Engadine School 1932-1982, Engadine Public School, Engadine NSW, 1983, p 19

${ }^{7}$ Joan Thompson, Engadine, New South Wales: An Outline History, Lions Club of Engadine, Engadine NSW, 1991, p 22 